\title{
In Vitro or In Vivo Models, the Next Frontier for Unraveling Interactions between Malassezia spp. and Hosts. How Much Do We Know?
}

\author{
Maritza Torres ${ }^{1}$, Hans de Cock $^{2}{ }^{\circledR}$ and Adriana Marcela Celis Ramírez ${ }^{1, *}$ \\ 1 Grupo de Investigación Celular y Molecular de Microorganismos Patógenos (CeMoP), Departamento de \\ Ciencias Biológicas, Universidad de los Andes, Carrera $1 \mathrm{~N}^{\circ}$ 18A-12, Bogotá, Bogotá D.C. 11711, Colombia; \\ marit-to@uniandes.edu.co \\ 2 Microbiology, Department of Biology, Faculty of Science, Institute of Biomembranes, Utrecht University, \\ Padualaan 8, 3584 CH Utrecht, The Netherlands; h.decock@uu.nl \\ * Correspondence: acelis@uniandes.edu.co
}

Received: 21 July 2020; Accepted: 10 August 2020; Published: 28 August 2020

\begin{abstract}
Malassezia is a lipid-dependent genus of yeasts known for being an important part of the skin mycobiota. These yeasts have been associated with the development of skin disorders and cataloged as a causal agent of systemic infections under specific conditions, making them opportunistic pathogens. Little is known about the host-microbe interactions of Malassezia spp., and unraveling this implies the implementation of infection models. In this mini review, we present different models that have been implemented in fungal infections studies with greater attention to Malassezia spp. infections. These models range from in vitro (cell cultures and ex vivo tissue), to in vivo (murine models, rabbits, guinea pigs, insects, nematodes, and amoebas). We additionally highlight the alternative models that reduce the use of mammals as model organisms, which have been gaining importance in the study of fungal host-microbe interactions. This is due to the fact that these systems have been shown to have reliable results, which correlate with those obtained from mammalian models. Examples of alternative models are Caenorhabditis elegans, Drosophila melanogaster, Tenebrio molitor, and Galleria mellonella. These are invertebrates that have been implemented in the study of Malassezia spp. infections in order to identify differences in virulence between Malassezia species.
\end{abstract}

Keywords: in vitro; in vivo; animal model; Malassezia; infection; host-pathogen interaction; Galleria mellonella

\section{Introduction}

Malassezia is a lipid-dependent genus of yeasts found as commensals on human and animal skin [1,2]. Under specific conditions, these yeasts have been associated with skin diseases [3], Crohn's disease, the exacerbation of colitis [4], Parkinson's disease [5], pancreatic ductal adenocarcinoma [6], and fungemia [7-9] (Table 1). Factors determining the outcome of host-microbe interactions are multifactorial, involving environmental conditions like temperature and humidity, but also host factors and the predisposition of the host, which may be related to genetic factors and impairment in the immune response [10,11]. In addition, the virulence factors of Malassezia are likely to be involved. Malassezia spp. are generally regarded as opportunistic pathogens but how this skin commensal contributes to skin diseases remains a matter of debate. Studying the lifestyle of Malassezia spp. in model organisms is expected to contribute to unraveling this long-standing issue.

Even though Malassezia was described for the first time in 1846 and has been studied for a long time, relatively little is known about its interactions with the host. In part, this is due to the specific nutritional requirements of the yeast [1,2]. The fact that Malassezia requires fatty acids in media for 
growth has complicated the development of in vitro and in vivo models [12,13]. Many studies have addressed and compared the relative abundances of Malassezia species on the healthy and diseased skin of hosts [2]. Clearly, these species are regarded as skin commensals, which makes it more complex to determine their direct role in disease development. They were proposed to modulate the immune response through different mechanisms. For example, the composition of the cell wall contributes to the evasion of phagocytosis and a decrease in the release of proinflammatory cytokines by immune cells (IL-1 $\beta$, IL-6 and TNF- $\alpha$ ) [14], and the induction of IL-17 that leads to skin inflammation $[15,16]$ and the indolic compounds that may inhibit the respiratory burst of neutrophils [17-21]. Furthermore, nutritional requirements may lead to the release of fatty acids that can contribute to skin irritation [10]. However, how these properties contribute to virulence has not been studies in depth in different infection models.

Malassezia yeasts are prominent members of the skin mycobiota and are considered to be commensals. Understanding the transition from a commensal microorganism to a pathogen in skin and systemic diseases is a major aim in current research. Besides, identifying the predisposing and risk factors of the host that contribute to this transition and also the response of the yeasts to these changing conditions can be studied and may help in the development of new therapeutic alternatives. The aforementioned goals require the implementation of infection models in which the virulence properties of Malassezia spp. can be studied. Depending on the formulation of the research question, different types of infection models might be used. However, to unravel host-microbe interactions, it is necessary to study infections in more than one model since each model system has its own properties and limitations. This review aims to show different infection models that have been used in the study of the Malassezia genus to understand the virulence properties of these yeasts and we will describe novel alternative models that are gaining importance in this field.

Table 1. Diseases associated with Malassezia spp.

\begin{tabular}{|c|c|c|c|c|}
\hline Disease & Clinical Findings & Species Involved & $\begin{array}{c}\text { Most Commonly Affected } \\
\text { Population }\end{array}$ & References \\
\hline $\begin{array}{c}\text { Pityriasis } \\
\text { versicolor (PV) }\end{array}$ & $\begin{array}{l}\text { Macules on the trunk and arms; the } \\
\text { skin lesions are hypopigmented and } \\
\text { hyperpigmented }\end{array}$ & $\begin{array}{c}\text { Malassezia globosa, } \\
\text { Malassezia sympodialis, } \\
\text { and Malassezia furfur }\end{array}$ & $\begin{array}{l}\text { Young adults and rarely } \\
\text { children and older adults }\end{array}$ & {$[3,22-27]$} \\
\hline $\begin{array}{l}\text { Dandruff/seborrheic } \\
\text { dermatitis (D/SD) }\end{array}$ & $\begin{array}{l}\text { Flaking and erythema in sebum-rich } \\
\text { areas like the scalp, nostrils, chest, } \\
\text { and eyebrows }\end{array}$ & $\begin{array}{l}\text { M. globosa, Malassezia restricta, } \\
\text { M. furfur, and Malassezia obtusa }\end{array}$ & $\begin{array}{l}\text { Elders, infants, children in } \\
\text { puberty and HIV patients }\end{array}$ & {$[3,25,27-33]$} \\
\hline Atopic dermatitis (AD) & $\begin{array}{l}\text { Chronic inflammatory illness with } \\
\text { pruritic eczematous lesions. } \\
\text { Malassezia has been proposed to act as } \\
\text { an exacerbator }\end{array}$ & $\begin{array}{l}\text { M sympodialis, M. globosa, } \\
\text { M. furfur, M. restricta, } \\
\text { Malassezia japonica, } \\
\text { Malassezia yamatoensis, } \\
\text { and M. slooffiae }\end{array}$ & $\begin{array}{l}\text { Adults with genetic and } \\
\text { environmental } \\
\text { predisposing factors }\end{array}$ & {$[3,27,34-38]$} \\
\hline Folliculitis & $\begin{array}{l}\text { Small dome-shaped papules localized } \\
\text { around follicular areas, mainly in the } \\
\text { back, chest, and shoulders. The } \\
\text { papules can evolve into pustules }\end{array}$ & $\begin{array}{l}\text { M. globosa, M. restricta, } \\
\text { M. sympodialis, M. furfur, } \\
\text { and M. pachydermatis }\end{array}$ & $\begin{array}{l}\text { Teenagers and young } \\
\text { adult males }\end{array}$ & {$[3,25,26,31,32]$} \\
\hline Psoriasis & $\begin{array}{l}\text { Chronic skin disease, characterized by } \\
\text { hyperproliferation and } \\
\text { hyperkeratinization of the epidermis. } \\
\text { Malassezia may augment } \\
\text { inflammation and the severity of the } \\
\text { disorder }\end{array}$ & $\begin{array}{l}\text { M. globosa, } M \text {. furfur, } \\
\text { M. sympodialis, } M \text {. restricta, } \\
\text { and M. slooffiae }\end{array}$ & $\begin{array}{l}\text { Patients with psoriasis, mainly } \\
\text { on the scalps of young adults }\end{array}$ & {$[3,27,37-42]$} \\
\hline Crohn’s disease & $\begin{array}{l}\text { Inflammatory bowel disease } \\
\text { characterized by altered immune } \\
\text { response to intestinal microbiota. } \\
\text { Malassezia yeasts in the gut may } \\
\text { increase the severity of the disease }\end{array}$ & M. restricta & $\begin{array}{l}\text { Crohn's disease patients } \\
\text { carrying the CARD } 9^{S 12 N} \\
\text { risk allele }\end{array}$ & {$[4,43]$} \\
\hline Parkinson's disease & $\begin{array}{l}\text { Neurodegenerative disease. } \\
\text { Seborrheic dermatitis has been } \\
\text { strongly associated with this disease }\end{array}$ & $\begin{array}{l}\text { M. globosa, M. restricta, } \\
\text { M. furfur, and M. obtusa }\end{array}$ & $\begin{array}{l}\text { Elders. Risk increases after a } \\
\text { seborrheic } \\
\text { dermatitis diagnosis }\end{array}$ & [5] \\
\hline $\begin{array}{l}\text { Pancreatic ductal } \\
\text { adenocarcinoma }\end{array}$ & Carcinoma due to fungal dysbiosis & M. globosa & $\begin{array}{l}\text { Individuals with oncogenic } \\
\text { Kras that induces } \\
\text { inflammation, resulting in } \\
\text { fungal dysbiosis }\end{array}$ & [6] \\
\hline Invasive infections & $\begin{array}{l}\text { Fungemia, endocarditis, } \\
\text { bronchopneumonia, respiratory } \\
\text { distress, splenic lesions, etc. }\end{array}$ & $\begin{array}{l}\text { M. furfur, M. pachydermatis, } \\
\text { M. sympodialis, and M. restricta }\end{array}$ & $\begin{array}{l}\text { Low-weight neonates and } \\
\text { immunocompromised patients }\end{array}$ & {$[3,7,8,26,44-51]$} \\
\hline
\end{tabular}




\section{Infection Models as a Way to Understand Host-Microbe Interactions}

Little is known about the virulence properties and infection mechanisms of Malassezia spp., and the implementation of infection models may allow for the evaluation of the interaction of these yeasts with hosts, the virulence of different species or strains of a specific species, and antifungal activity. There are different types of suitable models in which virulence and infection can be studied, but it is critical to realize that the results obtained in each model provide partial answers, as was mentioned before. It is therefore important to study virulence properties in different in vitro and in vivo models and the results obtained can provide complementary answers [52-55].

One of the infection models that may help to unravel host-microbe interactions is in vitro models, which have been used since the 1960s [55]. In vitro models are generally easier to handle, the majority of factors can be controlled, the evaluation of drug activity is more accurate, and, in some cases, they are cheaper than using animal models. These models can also be cataloged as ex vivo models [52,56,57], like cultured cells, removed organs, and skin equivalents or dermis equivalents [54,58,59]. As good as the in vitro models are, they do not fully reproduce the host-microbe interactions that occur, for example, on the skin.

Contrary to in vitro models, the in vivo models mimic the complexity of the host response better $[53,54,57,60]$. These are rather diverse and can vary from mammalian models to insect models. Mammalian models are phylogenetically the closest to human beings and, generally, are regarded as more accurately reproducing the host-microbe interaction, known as fidelity $[52,54,57]$. Additionally, many of these models are well characterized, allowing for genetic modifications to reach a desirable condition. The drawbacks of these models are the high cost of feeding and maintenance, the limited number of individuals, the ethical implications, and the need for trained personnel to handle the animals [54]. These drawbacks can be solved by the implementation of alternative animal models, like invertebrates.

Invertebrate animal models have recently gained importance in fungal research since studies have shown that the microbial virulence factors involved in infections in mammals are the same as those involved in invertebrate infections [53]. In fact, it seems that different aspects of the innate immune response in vertebrates and invertebrates are shared and represent a conserved trait, which means that human pathogens, at least in part, interact similarly with both immune systems [53,61]. The innate immune responses in invertebrate models are comparable to, for example, the human immune response to fungi via Toll-like receptors, which were originally discovered in Drosophila melanogaster [62], a model system already used with Malassezia [63], and also present in Caenorhabditis elegans [64]. Besides, the well-developed phagocytic system in lepidopterous and coleopterous larvae parallels the process of phagocytosis in mammalian systems [53,60,65-69].

\subsection{In Vitro Models of Host-Microbe Interaction}

In fungal infection research, the in vitro (ex vivo) models have been used to elucidate the mechanisms of interaction between fungi and their hosts. Indeed, an ex vivo model allows for the identification of the specific host tissue response to a pathogen, but it does not depict the whole host response $[52,54,57]$. An example of this is the implementation of keratinocytes to evaluate the response of these cells to skin-related fungal infections. Trichophyton rubrum was shown to induce the production of skin-derived antimicrobial peptides (AMPs) in primary keratinocytes, which may help the host to control dermatophyte infection [70]. Similarly, this model has been used as an infection model for Candida albicans, identifying the induction of proinflammatory cytokine production [71] and proteins involved in fungal adhesion to keratinocytes and interaction with the host [72].

The co-culturing of human keratinocytes with $M$. furfur yeasts was used to evaluate the activity of the cecropin A(1-8)-magainin 2(1-12) hybrid peptide analog P5 (an AMP). This research showed that this therapeutic alternative can indeed inhibit $M$. furfur growth without causing damage to keratinocytes. Moreover, AMPs can also modulate the inflammatory response of keratinocytes; this opens up the opportunity to evaluate new therapeutic alternatives in co-cultures of Malassezia and 
human keratinocytes, evaluating not just the drug effect on the pathogen but also the drug effect on and via the host [73]. Other studies have reported that Malassezia can induce or repress the production of cytokines in keratinocytes. The level of production depends on the species [74-76], the growth phase, and the hydrophobicity [77], and is affected by keratinocyte invasion and the survival of the pathogen inside the host cells [78]. In addition, it has been observed that M. pachydermatis, a zoophilic species, can invade human keratinocytes (12.1\%) [79] and induce a strong inflammatory response during the first $24 \mathrm{~h}$ after coincubation $[79,80]$. In contrast, $M$. furfur has shown a lower induction of the inflammatory response, something that may be related to the avoidance of phagocytosis [78]. Interestingly, the presence of a capsule-like lipid layer may reduce the pro-inflammatory cytokine production in keratinocytes, as a way to evade the immune response [81].

In addition, the role of some factors that are excreted by species of Malassezia can be elucidated through in vitro model experiments. For example, the extracellular nanovesicles of M. sympodialis were co-cultured with keratinocytes and monocytes, demonstrating for the first time that these small structures are phagocytized by keratinocytes and monocytes [34]. Later, it was demonstrated that these nanovesicles play an important role in activating the keratinocytes as part of the cutaneous defense against Malassezia [82]. Furthermore, M. furfur has also been shown to secrete extracellular vesicles that can induce the production of pro-inflammatory cytokines in human keratinocytes. Additionally, similar to what was reported in M. sympodialis, the vesicles secreted by M. furfur are phagocytized by keratinocytes [83].

Another in vitro model is the skin equivalent (SE) generated from the isolation and cultivation of fibroblasts and keratinocytes. This system allowed the growth of an inoculum of $1 \times 10^{2} \mathrm{CFU} / \mathrm{mL}$ of $M$. furfur, which grew to $1 \times 10^{4} \mathrm{CFU} / \mathrm{mL}$, which could mean that SE may produce and release the nutrients necessary for Malassezia to grow on this surface. This model appeared to mimic the lipid production by the host since the culturing media did not contain these lipids [58], but care must be taken that growth is not due to lipids associated with yeast cells and/or carried over from lipid-rich media used for pre-culturing. Similar to SE, there are other models that may allow for the understanding of the host response to Malassezia. For example, the reconstructed human epidermis (RHE) offers the opportunity to follow the progress of the infection over time and measure products of the immune response at every time point. In this case, it has been reported that M. furfur and $M$. sympodialis suppressed the inflammatory response after $48 \mathrm{~h}$, thereby evading the host immune system. Additionally, this model showed again that the keratinocyte response pattern depends on the Malassezia species used, indicating that virulence properties and mechanisms of pathogenesis differ between them [59].

\subsection{In Vivo Models of Host-Pathogen Interactions}

\subsubsection{Mammalian Models of Host-Pathogen Interactions}

Mammalian invivo fungal infection models include mice, rats, guinea pigs, dogs, and rabbits $[54,57,84,85]$. In fungi, these models have allowed for the elucidation of the role of virulence factors, like the formation of biofilms of Candida albicans using rabbits and rats as infection models [57]. Immunosuppressed rats and mice have also been used as animal models to study invasive rhinosinusitis caused by Aspergillus fumigatus [86] and drug evaluation in pulmonary aspergillosis [87]. Furthermore, mice models were used to establish keratitis infections with fluorescently labeled Fusarium solani, allowing for the in vivo observation of the pathogens during infection [88].

For Malassezia, the implementation of a host model has been difficult due to the weak virulence of the species of this genus. The first attempts to develop a suitable model for Malassezia failed because an infection could not be established in the animal model or the infection was resolved in a short time period. In 1940, Moore et al. inoculated M. furfur directly on the intact skin of rabbits, guinea pigs, rats, and mice, which resulted in no establishment of the infection unless they were infected by intracutaneous or intratesticular inoculation [85]. The evaluation of the efficacy of antifungal 
treatments against $M$. furfur in guinea pigs was possible but required daily direct inoculation on intact skin for one week, which caused skin alteration that resembled SD [89]. Similar results were observed for $M$. restricta inoculated directly on the skin surface of guinea pigs; wherein severe inflammation was observed after repeated inoculation every $24 \mathrm{~h}$ over 7 days. The skin inflammation lasted for 52 days and resembled SD. Furthermore, in this study, it was possible to evaluate the antifungal activity of ketoconazole and luliconazole, showing that the efficacy of ketoconazole is correlated with clinical findings using ketoconazole as an antifungal agent against Malassezia spp. For luliconazole, it was observed that this antifungal significantly reduced $M$. restricta rDNA copies and skin lesions. Taken together, these results demonstrated the suitability of the guinea pig, not just as an infection model, but also to evaluate antifungal activity [90].

Dogs were also used to model external otitis caused by M. pachydermatis; this was done through the instillation of M. pachydermatis inoculum into the external ear canal. The aim of this inoculation was to evaluate the activity of antifungals on external otitis development. Dogs were examined daily and a microscopical examination of ear exudate was done. The results showed the development of external otitis with an erythematous ear canal and exudate production. Additionally, abundant M. pachydermatis yeasts were recovered in cultures from the samples [91].

A couple of experiments have been conducted in rabbits, inoculated directly on the surface of the skin with or without occlusion with a plastic film over the inoculated area to favor colonization; this led to the occurrence of lesions on the skin and the appearance of mycelial structures in histological studies. Again, it was observed that, as soon as inoculation with yeast cells was discontinued, spontaneous healing occurred. It was, furthermore, evident that infection only occurred when occlusion was employed [92-94]. The presence of Malassezia in healthy skin and the high development of seborrheic dermatitis (SD) infections in acquired immune deficiency syndrome (AIDS) patients led to the belief that these yeasts were opportunistic $[95,96]$. In that way, new strategies to mimic the conditions of susceptible hosts were implemented. In 2004, Oble et al. developed a novel transgenic T-cell model in mice, in which spontaneous SD-like disease developed. Using anti-fungal staining, ovoid structures in primary lesions were observed. Furthermore, antifungal treatment resulted in the reversion of clinical symptoms. Although fungi were not isolated and characterized from the lesions, overgrowth by Malassezia spp. seems plausible, suggesting that infections only occur under conditions of severe immunological impairment [97].

Starting from this point, it is clear that animal models must have some kind of predisposition or repetitive exposure to successfully develop fungal infection with Malassezia. Yamasaki el al. developed a new deficient Mincle mouse model for Malassezia. Mincle, also known as Clec4e, is a PRR that recognizes the PAMP mannosyl-fatty acid in Malassezia. With the Mincle-deficient mice, it was demonstrated that the recognition of this PAMP induced the release of the cytokines Il- 6 and TNF in the host, similarly to that observed in Malassezia-induced lesions in humans [98]. Another way of causing immunosuppression in animal models is through the employment of chemical substances like hydrocortisone and cyclophosphamide, which results in a different type of immunosuppression. The latter results in neutropenic animals [99].

Predisposing factors include skin barrier disruption. In 2019, Sparber et al. demonstrated that epicutaneous infection by Malassezia spp. can be established by disrupting skin integrity using an adhesive tape on the dorsal skin of the ear of a mouse. This study showed that Malassezia induces the release of IL-17, which stimulates tissue inflammation, agreeing with findings in atopic dermatitis [15]. Recently, a new model for experimental psoriasis has been proposed, wherein imiquimod was employed to induce psoriasis-like dermatitis in a murine model. The results from this study support the idea that the presence of Malassezia on the skin may augment the skin disorder or induce it [41]. As can be seen with respect to mammal models, new in vivo alternatives have now been proposed that facilitate Malassezia infection in animals. 


\subsubsection{In Vivo Alternative Models of Host-Microbe Interactions}

In general, in vitro studies allow for the finding of patterns that require subsequent testing and validation in in vivo infection systems; ethical considerations have especially pushed the development of new model systems. With respect to animal treatment, Russell and Burch proposed the 3Rs strategy (replacement, reduction, and refinement). This strategy leads to reducing the use of mammals and the replacement of these with alternative models; like computer, in vitro, alternative vertebrate (Danio rerio) [100], and invertebrate models [101]. In general, invertebrate alternatives used to model fungal infections like amoeboid models [53,102], Caenorhabditis elegans [103-105], Drosophila melanogaster [63,106,107], Tenebrio molitor [108], Bombyx mori [60], and Galleria mellonella $[65,67,109,110]$ (Figure 1 and Table 1) have gained importance, amongst others, as these present an innate immune response similar to that found in mammals. Furthermore, microbial virulence factors play similar roles in mammals and invertebrate systems $[53,106,111]$. The results obtained with these models correlated with results obtained in mammalian models, validating the invertebrates as infection models [106,111-116]. Furthermore, the attractive features of these models include the low cost of feeding and the higher number of organisms able to be stored in a small space and used in a single experiment [60].
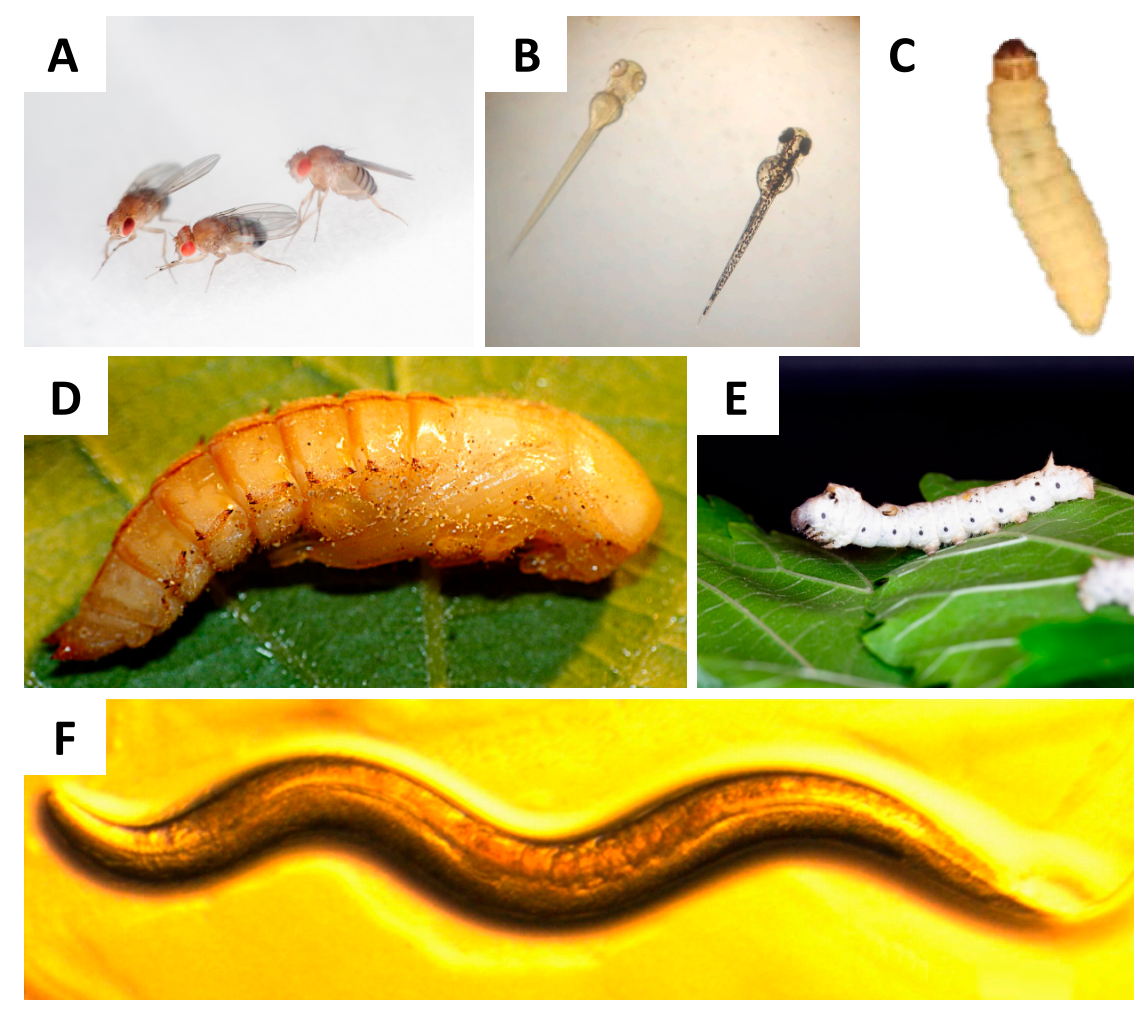

Figure 1. Alternative in vivo models for host-microbe interaction studies. (A) Adult D. melanogaster fly, whose size is approximately $3 \mathrm{~mm}$. Original photograph by Flickr user NASA's Marshall Space Flight Center, CC BY-SA 2.0 license. (B) Danio rerio larval size can range from $3.5 \mathrm{~mm}$ to $11 \mathrm{~mm}$ and, as can be seen, larvae are transparent, this facilitates monitoring the progress of the infection. Original photograph by Flickr user MichianaSTEM, CC BY-SA 2.0 license. (C) G. mellonella larval size ranges from $2 \mathrm{~cm}$ to $3 \mathrm{~cm}$ and its weight ranges between $200 \mathrm{mg}$ and $300 \mathrm{mg}$, making it easy to manipulate and inoculate. (D) T. molitor pupae, easy to breed and the size at the 2 nd instar is similar to that of G. mellonella. Original photograph by Flickr user Edithvale-Australia Insects and Spiders, CC BY-SA 2.0 license. (E) B. mori larvae, these larvae are large and their weight is in the range of $900 \mathrm{mg}$ to $1000 \mathrm{mg}$. Original photograph by Flickr user Gianluigi Bertin, CC BY-SA 2.0 license. (F) C. elegans nematodes, which grow to $1 \mathrm{~mm}$. Original photograph by Flickr user NIH Image Gallery, CC BY-SA 2.0 license. 
Table 2. In vitro and in vivo models available for Malassezia spp. infection studies.

\begin{tabular}{|c|c|c|c|c|c|}
\hline Infection Model & Cost & Inoculation & Advantages & Disavantages & References \\
\hline Keratinocyte culture & High & -Co-culture & $\begin{array}{l}\text {-Controlled conditions } \\
\text {-Just one type of cell }\end{array}$ & $\begin{array}{l}\text {-It does not represent the complex } \\
\text { interactions with the host }\end{array}$ & {$[52,54,74-81,83]$} \\
\hline Murine model & High & $\begin{array}{l}\text {-Oral gavage } \\
\text {-Inoculation through the tail vein } \\
\text {-Inhalation and intranasal administration } \\
\text {-Direct inoculation } \\
\text {-Ocular } \\
\text {-Intracranial } \\
\text {-Intraperitoneal }\end{array}$ & $\begin{array}{l}\text {-Well-defined inoculation routes } \\
\text {-Immune response is similar to a human's, } \\
\text { with innate and adaptative immune response } \\
\text {-Mimimcs human infection and disease } \\
\text {-Annotated genome } \\
\text {-Available mutants }\end{array}$ & $\begin{array}{l}\text {-Ethical issues } \\
\text {-Bigger space for storage } \\
\text {-Longer generation time } \\
\text {-Trained personnel to handle the models } \\
\text {-Immune suppression required }\end{array}$ & {$[57,60,117,118]$} \\
\hline $\begin{array}{c}\text { Amoeboid model } \\
\text { (Acanthamoeba castellani) }\end{array}$ & Low & -Co-incubation & $\begin{array}{l}\text {-Controlled conditions } \\
\text {-Inoculum quantification } \\
\text {-Available mutants } \\
\text {-Incubation at } 37^{\circ} \mathrm{C} \\
\text {-Phagocytosis assays } \\
\text {-Short life cycle } \\
\text {-Annotated genome }\end{array}$ & $\begin{array}{l}\text {-Undesired mutation and loss of phagocytic } \\
\text { abilities in long-cultured strains }\end{array}$ & {$[53,54,102,119,120]$} \\
\hline $\begin{array}{l}\text { Zebrafish larvae } \\
\text { (Danio rerio) }\end{array}$ & Low & $\begin{array}{l}\text {-Microinjection into the caudal vein, } \\
\text { notochord, duct of Cuvier, hindbrain } \\
\text { ventricle, eye, peritoneal cavity, or muscle } \\
\text { - exposure by immersion }\end{array}$ & $\begin{array}{l}\text {-Short generation time } \\
\text {-Annotated genome sequence } \\
\text {-Available mutants } \\
\text {-Transparency } \\
\text {-High-throughput screening } \\
\text {-Innate immune response similar to that of humans }\end{array}$ & $\begin{array}{l}\text {-In larval stage, there is no adaptative } \\
\text { immune response } \\
\text {-Ethical issues in some countries } \\
\text {-Difficult to handle }\end{array}$ & {$[100,118,121-126]$} \\
\hline Caenorhabditis elegans & Low & $\begin{array}{l}\text {-Exposure of larvae by immersion (feeding } \\
\text { and contact with the cuticle) }\end{array}$ & $\begin{array}{l}\text {-Short generation time } \\
\text {-Small size } \\
\text {-Easy to grow } \\
\text {-Annotated genome sequence } \\
\text {-Available mutants } \\
\text {-Innate immune response similar to that of humans } \\
\text {-Results correlated with results from mammals }\end{array}$ & $\begin{array}{l}\text {-There is no adaptative immune response } \\
\text {-Difficult to inoculate and quantify } \\
\text { the inoculum }\end{array}$ & {$[87,127]$} \\
\hline $\begin{array}{l}\text { Silkworm } \\
\text { (Bombyx mori) }\end{array}$ & Low & $\begin{array}{l}\text {-Microinjection into the haemocoel } \\
\text {-Oral (puncture) }\end{array}$ & $\begin{array}{l}\text {-Inoculum quantification } \\
\text {-High inoculum volume } \\
\text {-Results correlated with results from mammals } \\
\text {-Innate immune response similar to that of humans }\end{array}$ & -No adaptative immune response & {$[60,118,128]$} \\
\hline Drosophila melanogaster & Low & -Puncture in the dorsal side of the thorax & $\begin{array}{l}\text {-Annotated genome sequence } \\
\text {-Available mutants } \\
\text {-Innate immune response similar to that of humans }\end{array}$ & $\begin{array}{l}\text {-No adaptative immune response } \\
\text {-Difficult to inoculate and quantify the } \\
\text { inoculum }\end{array}$ & {$[63,106,129]$} \\
\hline Galleria mellonella & Low & $\begin{array}{l}\text { Microinjection directly to the haemocoel } \\
\text {-Topical } \\
\text {-Oral }\end{array}$ & $\begin{array}{l}\text {-Inoculum quantification } \\
\text {-Wide range of temperatures } \\
\text {-Innate immune response similar to that of humans } \\
\text {-Available immune response transcriptome } \\
\text {-Results correlated with results from mammals }\end{array}$ & -No adaptative immune response & {$[67,109,118,119,130-133]$} \\
\hline
\end{tabular}


In the field of Malassezia research, hardly any work has been published with alternative in vivo models and the implementation of invertebrates as model systems is very recent. In 2018, Brilhante et al. implemented for the first time the C. elegans larva as an infection model for M. pachydermatis. In this study, C. elegans larvae were exposed to M. pachydermatis by placing the larvae in plates containing the yeasts for a period of two hours at $25^{\circ} \mathrm{C}$. The viability of the nematodes was evaluated every $24 \mathrm{~h}$ and the results showed that, after $96 \mathrm{~h}$, the nematodes exposed to the yeast had significantly higher mortality (ranging from $48 \%$ to $95 \%$ ) than the control nematodes [134]. After that, in the same year, Silva et al. also evaluated the virulence of $M$. furfur, $M$. sympodialis, and M. yamatoensis under different growth conditions. The implementation of C. elegans larvae resulted in the identification of different virulence patterns depending on the lipid supplementation of the pre-culture medium. The co-culture of larvae with Malassezia spp. grown in media that was not supplemented with lipids resulted in lower larval survival. In the same study, a second model was implemented. T. molitor larvae were inoculated with a yeast suspension, and the larvae were shown, as in the case of $C$. elegans, to have higher survival when inoculated with $M$. furfur grown in a lipid-supplemented medium [135]. These two models allowed them to assess the virulence of three species of Malassezia under different growth conditions. However, more research needs to be done to understand this phenomenon.

In addition to T. molitor larvae, other insects have been implemented recently as an infection model for Malassezia. That is the case for D. melanogaster. Wild type (WT) and Toll-deficient adult flies were inoculated with five different inoculum concentrations of $M$. pachydermatis. The results showed that WT flies were resistant to the infection and that Toll-deficient flies inoculated with the highest inoculum concentrations showed a significantly reduced survival as compared to the control. These findings were corroborated with a decrease in fungal burden in WT flies and an absence of yeasts in histological investigations, contrasting to what was observed in the Toll-deficient flies [63]. These results demonstrated the opportunistic character of M. pachydermatis and showed the potential of the use of immune-deficient mutant flies to study the pathogenesis of Malassezia.

The G. mellonella larva was first used as a fungal infection model in 2000. In that study, the virulence of $C$. albicans was evaluated and compared with the effect of inoculating the larvae with Saccharomyces cerevisiae. The results showed that inoculating the larvae with the former had a lethal effect. In contrast, S. cerevisiae was not shown to be pathogenic. Additionally, it was found that clinical isolates of C. albicans were more virulent as compared to reference strains (ATCC 10231, ATCC 44990, and MEN). These results correlated with findings in mammalian models [112]. After this, G. mellonella has been widely implemented as a fungal infection model to evaluate virulence $[111,116,119,131,136-138]$, virulence patterns related to biofilm formation [133], co-infections [113], pathogen morphogenesis [115], complex host responses [114,139-142], and antifungal susceptibility $[110,143-146]$ at $37^{\circ} \mathrm{C}$, which is an advantage of this lepidopteran, as it can be incubated at human physiological temperatures. The results of most of these studies have been shown to correlate with results obtained in mammalian models and also in humans. Indeed, the efficacy of antifungals tested in G. mellonella larvae against Cryptococcus spp. [110] and Candida spp. [146] have been shown to correlate with results in the murine model, C. elegans larvae, and in vitro models. Even though these results are interesting, there is a need to better understand this insect. At present, there is available information related to the immune response transcriptome [147] and the miRNAs involved in the regulation of the immune response [148] that can help to evaluate the host response to a specific pathogen. All of this together makes this insect a promising tool to elucidate the complex host-microbe interactions of Malassezia.

G. mellonella has been standardized as an infection model for M. furfur CBS 1878 and M. pachydermatis CBS 1879, two isolates from skin lesions. The inoculation of larvae with these two species showed that larval survival depended on the inoculum concentration (higher inoculum concentration led to lower survival, compared to lower inoculum concentration). Additionally, a lower virulence was observed for $M$. furfur as compared to $M$. pachydermatis at $33^{\circ} \mathrm{C}$ and $37^{\circ} \mathrm{C}$. This was evident by a decrease in larval survival, higher fungal burden, histological examination with a higher presence of hemocyte aggregates with melanin deposition, and a higher larval melanization, 
especially in larvae that were inoculated with $M$. pachydermatis and incubated at $37^{\circ} \mathrm{C}$. The higher virulence of $M$. pachydermatis was attributed to a high phospholipase activity and a high capacity of M. pachydermatis to form biofilms [149]. However, further studies are required to confirm these hypotheses. These results show that the G. mellonella larva is a suitable model and very useful to identify differences in the virulence between species or strains.

\section{Conclusions}

The use of both in vitro and in vivo models is important in unraveling the interactions between microbes and hosts, and a variety of models are indeed available (Figure 1 and Table 2). In vivo models clearly allow for the direct comparison of virulence and studies of pathogenic developments in the host, and are, in that respect, most attractive. Alternative models that can replace mammalian models on ethical grounds are favored to reduce the number of animals used in research. However, it is important to keep in mind that alternative models do not completely replace mammalian models. In short, insect larvae like the G. mellonella larva have been proven to be reliable models and produce results similar to those reported in the murine models, making it an interesting tool to decipher aspects of the host-microbe interactions of Malassezia.

Author Contributions: M.T. and A.M.C.R., Writing-Original draft preparation, A.M.C.R. and H.d.C., Writing-Review and editing. All authors have approved the final version. All authors have read and agreed to the published version of the manuscript.

Funding: This research was funded by the Faculty of Sciences, Universidad de los Andes grant number INV-2018-31-1252. All authors acknowledge financial provided by the Vice Presidency for Research \& Creation publication fund at the Universidad de los Andes.

Acknowledgments: We thank the Faculty of Sciences for financial support grant No. INV-2018-31-1252, the Vice-Presidency of Research and Creation and the department of languages and culture, Universidad de los Andes.

Conflicts of Interest: The authors declare that the research was conducted in the absence of any commercial or financial relationships that could be construed as a potential conflict of interest.

\section{References}

1. Juntachai, W.; Oura, T.; Murayama, S.Y.; Kajiwara, S. The lipolytic enzymes activities of Malassezia species. Med. Mycol. 2009, 47, 477-484. [CrossRef] [PubMed]

2. Wu, G.; Zhao, H.; Li, C.; Rajapakse, M.P.; Wong, W.C.; Xu, J.; Saunders, C.W.; Reeder, N.L.; Reilman, R.A.; Scheynius, A.; et al. Genus-Wide Comparative Genomics of Malassezia Delineates Its Phylogeny, Physiology, and Niche Adaptation on Human Skin. PLoS Genet. 2015, 11, 1-26. [CrossRef] [PubMed]

3. Theelen, B.; Cafarchia, C.; Gaitanis, G.; Bassukas, I.D.; Boekhout, T.; Dawson, T.L. Malassezia ecology, pathophysiology, and treatment. Med. Mycol. 2018, 56, S10-S25. [CrossRef] [PubMed]

4. Limon, J.J.; Tang, J.; Li, D.; Wolf, A.J.; Michelsen, K.S.; Funari, V.; Gargus, M.; Nguyen, C.; Sharma, P.; Maymi, V.I.; et al. Malassezia Is Associated with Crohn's Disease and Exacerbates Colitis in Mouse Models. Cell Host Microbe 2019, 25, 377-388. [CrossRef]

5. Laurence, M.; Benito-León, J.; Calon, F. Malassezia and Parkinson's disease. Front. Neurol. 2019, $10,758$. [CrossRef] [PubMed]

6. Aykut, B.; Pushalkar, S.; Chen, R.; Li, Q.; Abengozar, R.; Kim, J.I.; Shadaloey, S.A.; Wu, D.; Preiss, P.; Verma, N.; et al. The fungal mycobiome promotes pancreatic oncogenesis via activation of MBL. Nature 2019, 574, 264-267. [CrossRef]

7. Roman, J.; Bagla, P.; Ren, P.; Blanton, L.S.; Berman, M.A. Malassezia pachydermatis fungemia in an adult with multibacillary leprosy. Med. Mycol. Case Rep. 2016, 12, 1-3. [CrossRef]

8. Ochman, E.; Podsiadło, B.; Połowniak-Pracka, H.; Hagmajer, E.; Sowiński, P. Malassezia furfur sepsis in a cancer patient. Nowotw. J. Oncol. 2004, 54, 130-134.

9. Nagata, R.; Nagano, H.; Ogishima, D.; Nakamura, Y.; Hiruma, M.; Sugita, T. Transmission of the major skin microbiota, Malassezia, from mother to neonate. Pediatr. Int. 2012, 54, 350-355. [CrossRef] 
10. DeAngelis, Y.M.; Gemmer, C.M.; Kaczvinsky, J.R.; Kenneally, D.C.; Schwartz, J.R.; Dawson, T.L. Three etiologic facets of dandruff and seborrheic dermatitis: Malassezia fungi, sebaceous lipids, and individual sensitivity. J. Investig. Dermatol. Symp. Proc. 2005, 10, 295-297. [CrossRef]

11. Borelli, D.; Jacobs, P.H.; Nall, L. Tinea versicolor: Epidemiologic, clinical, and therapeutic aspects. J. Am. Acad. Dermatol. 1991, 25, 300-305. [CrossRef]

12. Leeming, J.P.; Notman, F.H. Improved Methods for Isolation and Enumeration of Malassezia furfur from Human Skin. J. Clin. Microbiol. 1987, 25, 2017-2019. [CrossRef] [PubMed]

13. Guého, E.; Midgley, G.; Guillot, J. The genus Malassezia with description of four new species. Antonie Leeuwenhoek Int. J. Gen. Mol. Microbiol. 1996, 69, 337-355. [CrossRef] [PubMed]

14. Ashbee, H.R.; Evans, E.G.V. Immunology of diseases associated with Malassezia species. Clin. Microbiol. Rev. 2002, 15, 21-57. [CrossRef] [PubMed]

15. Sparber, F.; De Gregorio, C.; Steckholzer, S.; Ferreira, F.M.; Dolowschiak, T.; Ruchti, F.; Kirchner, F.R.; Mertens, S.; Prinz, I.; Joller, N.; et al. The Skin Commensal Yeast Malassezia Triggers a Type 17 Response that Coordinates Anti-fungal Immunity and Exacerbates Skin Inflammation. Cell Host Microbe 2019, 25, 389-403. [CrossRef] [PubMed]

16. Sparber, F.; Ruchti, F.; Leibund Gut-Landmann, S. Host Immunity to Malassezia in Health and Disease. Front. Cell. Infect. Microbiol. 2020, 10, 198. [CrossRef]

17. Vlachos, C.; Schulte, B.M.; Magiatis, P.; Adema, G.J.; Gaitanis, G. Malassezia-derived indoles activate the aryl hydrocarbon receptor and inhibit Toll-like receptor-induced maturation in monocyte-derived dendritic cells. Br. J. Dermatol. 2012, 167, 496-505. [CrossRef]

18. Kim, S.-H.; Ko, H.-C.; Kim, M.-B.; Kwon, K.-S.; Oh, C.-K. The Effect of Detergents on the Morphology and Immunomodulatory Activity of Malassezia furfur. Ann. Dermatol. 2009, 21, 130-135. [CrossRef]

19. Kesavan, S.; Holland, K.T.; Ingham, E. The effects of lipid extraction on the immunomodulatory activity of Malassezia species in vitro. Med. Mycol. 2000, 38, 239-247. [CrossRef]

20. Youngchim, S.; Nosanchuk, J.D.; Pornsuwan, S.; Kajiwara, S.; Vanittanakom, N. The Role of L-DOPA on Melanization and Mycelial Production in Malassezia furfur. PLoS ONE 2013, 8, e63764. [CrossRef]

21. Sparber, F.; LeibundGut-Landmann, S. Host responses to Malassezia spp. in the mammalian skin. Front. Immunol. 2017, 8, 1614. [CrossRef] [PubMed]

22. Lyakhovitsky, A.; Shemer, A.; Amichai, B.; Boaz Amichai, C. Molecular analysis of Malassezia species isolated from Israeli patients with pityriasis versicolor. Int. J. Dermatol. 2013, 52, 231-233. [CrossRef]

23. Borelli, D. Pitiriasis versicolor por Malassezia ovalis. Mycopathologia 1985, 89, 147-153. [CrossRef] [PubMed]

24. Gupta, A.K.; Kohliyz, Y.; Faergemann, J.; Summerbell, R.C. Epidemiology of Malassezia yeasts associated with pityriasis versicolor in Ontario, Canada. Med. Mycol. 2001, 39, 199-206. [CrossRef] [PubMed]

25. Magiatis, P.; Pappas, P.; Gaitanis, G.; Mexia, N.; Melliou, E.; Galanou, M.; Vlachos, C.; Stathopoulou, K.; Skaltsounis, A.L.; Marselos, M.; et al. Malassezia yeasts produce a collection of exceptionally potent activators of the ah (dioxin) receptor detected in diseased human skin. J. Investig. Dermatol. 2013, 133, 2023-2030. [CrossRef] [PubMed]

26. Morrison, V.A.; Weisdorf, D.J. The spectrum of Malassezia infections in the bone marrow transplant population. Bone Marrow Transplant. 2000, 26, 645-648. [CrossRef]

27. Gupta, A.K.; Kohliy, Y.; Summerbell, R.C.; Faergemann, J. Quantitative culture of Malassezia species from different body sites of individuals with or without dermatoses. Med. Mycol. 2001, 39, 243-251. [CrossRef]

28. Hiruma, M.; Cho, O.; Hiruma, M.; Kurakado, S.; Sugita, T.; Ikeda, S. Genotype Analyses of Human Commensal Scalp Fungi, Malassezia globosa, and Malassezia restricta on the Scalps of Patients with Dandruff and Healthy Subjects. Mycopathologia 2014, 177, 263-269. [CrossRef]

29. Ro, B.I.; Dawson, T.L. The Role of Sebaceous Gland Activity and Scalp Microfloral Metabolism in the Etiology of Seborrheic Dermatitis and Dandruff. J. Investig. Dermatol. Symp. Proc. 2005, 10, 194-197. [CrossRef]

30. Nakabayashi, A.; Sei, Y.; Guillot, J. Identification of Malassezia species isolated from patients with seborrhoeic dermatitis, atopic dermatitis, pityriasis versicolor and normal subjects. Med. Mycol. 2000, 38, 337-341. [CrossRef]

31. Ashbee, H.R. Update on the genus Malassezia. Med. Mycol. 2007, 45, 287-303. [CrossRef] [PubMed]

32. Dokos, C.; Pana, Z.D.; Tragiannidis, A. Malassezia species: A rare cause of invasive fungal infections in immunocompromised patients. Curr. Fungal Infect. Rep. 2011, 5, 18-22. [CrossRef] 
33. Kamamoto, C.S.L.; Nishikaku, A.S.; Gompertz, O.F.; Melo, A.S.; Hassun, K.M.; Bagatin, E. Cutaneous fungal microbiome: Malassezia yeasts in seborrheic dermatitis scalp in a randomized, comparative and therapeutic trial. Dermatoendocrinology 2018, 9, e1361573. [CrossRef] [PubMed]

34. Johansson, H.J.; Vallhov, H.; Holm, T.; Gehrmann, U.; Andersson, A.; Johansson, C.; Blom, H.; Carroni, M.; Lehtiö, J.; Scheynius, A. Extracellular nanovesicles released from the commensal yeast Malassezia sympodialis are enriched in allergens and interact with cells in human skin. Sci. Rep. 2018, 8, 1-11. [CrossRef] [PubMed]

35. Jain, C.; Das, S.; Ramachandran, V.G.; Saha, R.; Bhattacharya, S.N.; Dar, S. Malassezia yeast and cytokine gene polymorphism in atopic dermatitis. J. Clin. Diagn. Res. 2017, 11, DC01-DC05. [CrossRef]

36. Glatz, M.; Bosshard, P.; Hoetzenecker, W.; Schmid-Grendelmeier, P. The Role of Malassezia spp. in Atopic Dermatitis. J. Clin. Med. 2015, 4, 1217-1228. [CrossRef]

37. Prohic, A.; Jovovic Sadikovic, T.; Krupalija-Fazlic, M.; Kuskunovic-Vlahovljak, S. Malassezia species in healthy skin and in dermatological conditions. Int. J. Dermatol. 2016, 55, 494-504. [CrossRef]

38. Kanda, N.; Tani, K.; Enomoto, U.; Nakai, K.; Watanabe, S. The skin fungus-induced Th1- and Th2-related cytokine, chemokine and prostaglandin E2 production in peripheral blood mononuclear cells from patients with atopic dermatitis and psoriasis vulgaris. Clin. Exp. Allergy 2002, 32, 1243-1250. [CrossRef]

39. Jagielski, T.; Rup, E.; Ziółkowska, A.; Roeske, K.; Macura, A.B.; Bielecki, J. Distribution of Malassezia species on the skin of patients with atopic dermatitis, psoriasis, and healthy volunteers assessed by conventional and molecular identification methods. BMC Dermatol. 2014, 14, 3. [CrossRef]

40. Rudramurthy, S.M.; Honnavar, P.; Chakrabarti, A.; Dogra, S.; Singh, P.; Handa, S. Association of Malassezia species with psoriatic lesions. Mycoses 2014, 57, 483-488. [CrossRef]

41. Hurabielle, C.; Link, V.M.; Bouladoux, N.; Han, S.-J.; Dean Merrill, E.; Lightfoot, Y.L.; Seto, N.; Bleck, C.K.E.; Smelkinson, M.; Harrison, O.J.; et al. Immunity to commensal skin fungi promotes psoriasiform skin inflammation. Proc. Natl. Acad. Sci. USA 2020, 117, 16465-16474. [CrossRef] [PubMed]

42. Lober, C.W.; Belew, P.W.; Rosenberg, W.; Bale, G. Patch Tests With Killed Sonicated Microflora in Patients With Psoriasis from the Departments of Medicine. Arch. Dermatol. 1982, 118, 322-325. [CrossRef] [PubMed]

43. Kellermayer, R.; Mir, S.A.V.; Nagy-Szakal, D.; Cox, S.B.; Dowd, S.E.; Kaplan, J.L.; Sun, Y.; Reddy, S.; Bronsky, J.; Winter, H.S. Microbiota separation and C-reactive protein elevation in treatment-naïve pediatric granulomatous crohn disease. J. Pediatr. Gastroenterol. Nutr. 2012, 55, 243-250. [CrossRef] [PubMed]

44. Iatta, R.; Battista, M.; Miragliotta, G.; Boekhout, T.; Otranto, D.; Cafarchia, C. Blood culture procedures and diagnosis of Malassezia furfur bloodstream infections: Strength and weakness. Med. Mycol. 2018, 56, 828-833. [CrossRef] [PubMed]

45. De St Maurice, A.; Frangoul, H.; Coogan, A.; Williams, J.V. Prolonged fever and splenic lesions caused by Malassezia restricta in an immunocompromised patient. Pediatr. Transplant. 2014, 18, E283-E286. [CrossRef]

46. Lee, J.; Cho, Y.G.; Kim, D.S.; Choi, S.I.; Lee, H.S. First case of catheter-related Malassezia pachydermatis fungemia in an adult. Ann. Lab. Med. 2018, 39, 99-101. [CrossRef]

47. Al-Sweih, N.; Ahmad, S.; Joseph, L.; Khan, S.; Khan, Z. Malassezia pachydermatis fungemia in a preterm neonate resistant to fluconazole and flucytosine. Med. Mycol. Case Rep. 2014, 5, 9-11. [CrossRef] [PubMed]

48. Iatta, R.; Cafarchia, C.; Cuna, T.; Montagna, O.; Laforgia, N.; Gentile, O.; Rizzo, A.; Boekhout, T.; Otranto, D.; Montagna, M.T. Bloodstream infections by Malassezia and Candida species in critical care patients. Med. Mycol. 2014, 52, 264-269. [CrossRef] [PubMed]

49. Chen, I.T.; Chen, C.C.; Huang, H.C.; Kuo, K.C. Malassezia furfur Emergence and Candidemia Trends in a Neonatal Intensive Care Unit during 10 Years: The Experience of Fluconazole Prophylaxis in a Single Hospital. Adv. Neonatal Care 2020, 20, E3-E8. [CrossRef]

50. Aguirre, C.; Euliarte, C.; Finquelievich, J.; de los Ángeles Sosa, M.; Giusiano, G. Fungemia and interstitial lung compromise caused by Malassezia sympodialis in a pediatric patient. Rev. Iberoam. Micol. 2015, 32, 118-121. [CrossRef]

51. Patron, R.L. A 34-Year-Old Man With Cough, Lung Nodules, Fever, and Eosinophilia. Clin. Infect. Dis. 2016, 63, 1525-1526. [CrossRef] [PubMed]

52. Swearengen, J.R. Choosing the right animal model for infectious disease research. Anim. Model. Exp. Med. 2018, 1, 100-108. [CrossRef] [PubMed]

53. Mylonakis, E.; Casadevall, A.; Ausubel, F.M. Exploiting amoeboid and non-vertebrate animal model systems to study the virulence of human pathogenic fungi. PLoS Pathog. 2007, 3, e101. [CrossRef] [PubMed] 
54. Capilla, J.; Clemons, K.V.; Stevens, D.A. Animal models: An important tool in mycology. Med. Mycol. 2007, 45, 657-684. [CrossRef] [PubMed]

55. White, R.L. What In Vitro Models of Infection Can and Cannot Do. Pharmacotherapy 2001, 21, 292 S-301S. [CrossRef]

56. Dalziel, J.E.; Dunstan, K.E.; Finch, S.C. Combined effects of fungal alkaloids on intestinal motility in an in vitro rat model. J. Anim. Sci 2013, 91, 5177-5182. [CrossRef]

57. Van Dijck, P.; Sjollema, J.; Cammue, B.P.A.; Lagrou, K.; Berman, J.; d’Enfert, C.; Andes, D.R.; Arendrup, M.C.; Brakhage, A.A.; Calderone, R.; et al. Methodologies for in vitro and in vivo evaluation of efficacy of antifungal and antibiofilm agents and surface coatings against fungal biofilms. Microb. Cell 2018, 5, 300-326. [CrossRef]

58. Holland, D.B.; Bojar, R.A.; Jeremy, A.H.T.; Ingham, E.; Holland, K.T. Microbial colonization of an in vitro model of a tissue engineered human skin equivalent-A novel approach. FEMS Microbiol. Lett. 2008, 279, 110-115. [CrossRef]

59. Pedrosa, A.F.; Lisboa, C.; Branco, J.; Pellevoisin, C.; Miranda, I.M.; Rodrigues, A.G. Malassezia interaction with a reconstructed human epidermis: Keratinocyte immune response. Mycoses 2019, 62, 932-936. [CrossRef]

60. Matsumoto, Y.; Sekimizu, K. Silkworm as an experimental animal for research on fungal infections. Microbiol. Immunol. 2019, 63, 41-50. [CrossRef]

61. Arvanitis, M.; Glavis-Bloom, J.; Mylonakis, E. Invertebrate models of fungal infection. Biochim. Biophys. Acta Mol. Basis Dis. 2013, 1832, 1378-1383. [CrossRef] [PubMed]

62. Lemaitre, B.; Nicolas, E.; Michaut, L.; Reichhart, J.-M.; Hoffmann, J.A. The dorsoventral regulatory gene cassette spätzle/Toll/cactus controls the potent antifungal response in Drosophila adults. Cell 1996, 86, 973-983. [CrossRef]

63. Merkel, S.; Heidrich, D.; Danilevicz, C.K.; Scroferneker, M.L.; Zanette, R.A. Drosophila melanogaster as a model for the study of Malassezia pachydermatis infections. Vet. Microbiol. 2018, 224, 31-33. [CrossRef]

64. Tenor, J.L.; Aballay, A. A conserved Toll-like receptor is required for Caenorhabditis elegans innate immunity. EMBO Rep. 2008, 9, 103-109. [CrossRef]

65. Trevijano-Contador, N.; Zaragoza, O. Immune response of Galleria mellonella against human fungal pathogens. J. Fungi 2019, 5, 3. [CrossRef] [PubMed]

66. Wojda, I. Immunity of the greater wax moth Galleria mellonella. Insect Sci. 2017, 24, 342-357. [CrossRef] [PubMed]

67. Pereira, T.; de Barros, P.; Fugisaki, L.; Rossoni, R.; Ribeiro, F.; de Menezes, R.; Junqueira, J.; Scorzoni, L. Recent advances in the use of Galleria mellonella model to study immune responses against human pathogens. J. Fungi 2018, 4, 128. [CrossRef]

68. Boguś, M.I.; Ligęza-Żuber, M.; Polańska, M.A.; Mosiewicz, M.; Włóka, E.; Sobocińska, M. Fungal infection causes changes in the number, morphology and spreading ability of Galleria mellonella haemocytes. Physiol. Entomol. 2018, 43, 214-226. [CrossRef]

69. Urbański, A.; Adamski, Z.; Rosiński, G. Developmental changes in haemocyte morphology in response to Staphylococcus aureus and latex beads in the beetle Tenebrio molitor L. Micron 2018, 104, 8-20. [CrossRef]

70. Firat, Y.H.; Simanski, M.; Rademacher, F.; Schröder, L.; Brasch, J.; Harder, J. Infection of keratinocytes with Trichophytum rubrum induces epidermal growth factor-dependent RNase 7 and human beta-defensin-3 expression. PLoS ONE 2014, 9, e93941. [CrossRef]

71. Wollina, U.; Kü, W.; Bulling, L.; Fü Nfstü Ck, C.; Knö, B.; Vennewald, I.; Hipler, U.-C.; Wollina, U. Candida albicans-induced inflammatory response in human keratinocytes. Mycoses 2004, 47, 193-199. [CrossRef]

72. Lopez, C.M.; Wallich, R.; Riesbeck, K.; Skerka, C.; Zipfel, P.F. Candida albicans uses the surface protein Gpm1 to attach to human endothelial cells and to keratinocytes via the adhesive protein vitronectin. PLoS ONE 2014, 9, e90796. [CrossRef] [PubMed]

73. Ryu, S.; Choi, S.Y.; Acharya, S.; Chun, Y.J.; Gurley, C.; Park, Y.; Armstrong, C.A.; Song, P.I.; Kim, B.J. Antimicrobial and anti-inflammatory effects of cecropin A(1-8)-magainin2(1-12) hybrid peptide analog P5 against Malassezia furfur infection in human keratinocytes. J. Investig. Dermatol. 2011, 131, 1677-1683. [CrossRef]

74. Watanabe, S.; Kano, R.; Sato, H.; Nakamura, Y.; Hasegawa, A. The effects of Malassezia yeasts on cytokine production by human keratinocytes. J. Investig. Dermatol. 2001, 116, 769-773. [CrossRef] [PubMed] 
75. Donnarumma, G.; Perfetto, B.; Paoletti, I.; Oliviero, G.; Clavaud, C.; Del Bufalo, A.; Guéniche, A.; Jourdain, R.; Tufano, M.A.; Breton, L. Analysis of the response of human keratinocytes to Malassezia globosa and restricta strains. Arch. Dermatol. Res. 2014, 306, 763-768. [CrossRef]

76. Ishibashi, Y.; Sugita, T.; Nishikawa, A. Cytokine secretion profile of human keratinocytes exposed to Malassezia yeasts. FEMS Immunol. Med. Microbiol. 2006, 48, 400-409. [CrossRef]

77. Akaza, N.; Akamatsu, H.; Takeoka, S.; Mizutani, H.; Nakata, S.; Matsunaga, K. Increased hydrophobicity in Malassezia species correlates with increased proinflammatory cytokine expression in human keratinocytes. Med. Mycol. 2012, 87, 802-810. [CrossRef] [PubMed]

78. Baroni, A.; Perfetto, B.; Paoletti, I.; Ruocco, E.; Canozo, N.; Orlando, M.; Buommino, E. Malassezia furfur invasiveness in a keratinocyte cell line (HaCat): Effects on cytoskeleton and on adhesion molecule and cytokine expression. Arch. Dermatol. Res. 2001, 293, 414-419. [CrossRef]

79. Buommino, E.; De Filippis, A.; Parisi, A.; Nizza, S.; Martano, M.; Iovane, G.; Donnarumma, G.; Tufano, M.A.; De Martino, L. Innate immune response in human keratinocytes infected by a feline isolate of Malassezia pachydermatis. Vet. Microbiol. 2013, 163, 90-96. [CrossRef]

80. Buommino, E.; Baroni, A.; Papulino, C.; Nocera, F.P.; Coretti, L.; Donnarumma, G.; De Filippis, A.; De Martino, L. Malassezia pachydermatis up-regulates AhR related CYP1A1 gene and epidermal barrier markers in human keratinocytes. Med. Mycol. 2018, 56, 987-993. [CrossRef]

81. Thomas, D.S.; Ingham, E.; Bojar, R.A.; Holland, K.T. In vitro modulation of human keratinocyte pro- and anti-inflammatory cytokine production by the capsule of Malassezia species. FEMS Immunol. Med. Microbiol. 2008, 54, 203-214. [CrossRef] [PubMed]

82. Vallhov, H.; Johansson, C.; Veerman, R.E.; Scheynius, A. Extracellular Vesicles Released from the Skin Commensal Yeast Malassezia sympodialis Activate Human Primary Keratinocytes. Front. Cell. Infect. Microbiol. 2020, 10, 6. [CrossRef] [PubMed]

83. Zhang, Y.J.; Han, Y.; Sun, Y.Z.; Jiang, H.H.; Liu, M.; Qi, R.Q.; Gao, X.H. Extracellular vesicles derived from Malassezia furfur stimulate IL-6 production in keratinocytes as demonstrated in in vitro and in vivo models. J. Dermatol. Sci. 2019, 93, 168-175. [CrossRef] [PubMed]

84. McCarthy, M.W.; Denning, D.W.; Walsh, T.J. Future research priorities in fungal resistance. J. Infect. Dis. 2017, 216, S484-S492. [CrossRef] [PubMed]

85. Moore, M.; Louis, S.; Pullar, A.; Hardwicke, R. LXXXIII.-Malassezia furfur, the cause of tinea versicolor cultivation of the organism and experimental production of the disease. Arch. Dermatol. Syphilol. 1940, 41, 253-260. [CrossRef]

86. Zhang, F.; An, Y.; Li, Z.; Zhao, C. A novel model of invasive fungal rhinosinusitis in rats. Am. J. Rhinol. Allergy 2013, 27, 361-366. [CrossRef]

87. Kurtz, M.B.; Bernard, E.M.; Edwards, F.F.; Marrinan, J.A.; Dropinski, J.; Douglas, C.M.; Armstrong, A.D. Aerosol and Parenteral Pneumocandins Are Effective in a Rat Model of Pulmonary Aspergillosis. Antimicrob. Agents Chemother. 1995, 39, 1784-1789. [CrossRef]

88. Zhang, H.; Wang, L.; Li, Z.; Liu, S.; Xie, Y.; He, S.; Deng, X.; Yang, B.; Liu, H.; Chen, G.; et al. A novel murine model of Fusarium solani keratitis utilizing fluorescent labeled fungi. Exp. Eye Res. 2013, 110, 107-112. [CrossRef]

89. Van Cutsem, J.; Van Gerven, F.; Fransen, J.; Schrooten, P.; Janssen, P.A.J. The in vitro antifungal activity of ketoconazole, zinc pyrithione, and selenium sulfide against Pityrosporum and their efficacy as a shampoo in the treatment of experimental pityrosporosis in guinea pigs. J. Am. Acad. Dermatol. 1990, 22, 993-998. [CrossRef]

90. Koga, H.; Munechika, Y.; Matsumoto, H.; Nanjoh, Y.; Harada, K.; Makimura, K.; Tsuboi, R. Guinea pig seborrheic dermatitis model of Malassezia restricta and the utility of luliconazole. Med. Mycol. 2020, 58, 820-826. [CrossRef]

91. Uchida, Y.; Mizutani, M.; Kubo, T.; Nakade, T.; Otomo, K. Otitis External Induced with Malassezia pachydermatis in Dogs and the Efficacy of Pimaricin. J. Vet. Med. Sci. 1992, 54, 611-614. [CrossRef]

92. Rosenberg, E.W.; Belew, P.; Bale, G. Effect of topical applications of heavy suspensions of killed malassezia ovalis on rabbit skin. Mycopathologia 1980, 72, 147-154. [CrossRef] [PubMed]

93. Faergemann, J. Experimental tinea versicolor in rabbits and humans with Pityrosporum orbiculare. J. Investig. Dermatol. 1979, 72, 326-329. [CrossRef] [PubMed] 
94. Faergemann, J.; Fredriksson, T. Experimental Infections in Rabbits and Humans with Pityrosporum orbiculare and P. ovale. J. Investig. Dermatol. 1981, 77, 314-318. [CrossRef] [PubMed]

95. Groisser, D.; Bottone, E.J.; Lebwohl, M. Association of Pityrosporum orbiculare (Malassezia furfur) with seborrheic dermatitis in patients with acquired immunodeficiency syndrome (AIDS). J. Am. Acad. Dermatol. 1989, 20, 770-773. [CrossRef]

96. Conant, M.A. The AIDS epidemic. J. Am. Acad. Dermatol. 1994, 31, S47-S50. [CrossRef]

97. Oble, D.A.; Collett, E.; Hsieh, M.; Ambjrn, M.; Law, J.; Dutz, J.; Teh, H.-S. A Novel T Cell Receptor Transgenic Animal Model of Seborrheic Dermatitis-Like Skin Disease. J. Investig. Dermatol. 2005, 124, 151-159. [CrossRef]

98. Yamasaki, S.; Matsumoto, M.; Takeuchi, O.; Matsuzawa, T.; Ishikawa, E.; Sakuma, M.; Tateno, H.; Uno, J.; Hirabayashi, J.; Mikami, Y.; et al. C-type lectin Mincle is an activating receptor for pathogenic fungus, Malassezia. Proc. Natl. Acad. Sci. USA 2009, 106, 1897-1902. [CrossRef]

99. Schlemmer, K.B.; Jesus, F.P.K.; Loreto, É.S.; Tondolo, J.S.M.; Ledur, P.C.; Dallabrida, A.; da Silva, T.M.; Kommers, G.D.; Alves, S.H.; Santurio, J.M. An experimental murine model of otitis and dermatitis caused by Malassezia pachydermatis. Mycoses 2018, 61, 954-958. [CrossRef]

100. Rosowski, E.E.; Knox, B.P.; Archambault, L.S.; Huttenlocher, A.; Keller, N.P.; Wheeler, R.T.; Davis, J.M. The zebrafish as a model host for invasive fungal infections. J. Fungi 2018, 4, 136. [CrossRef]

101. Doke, S.K.; Dhawale, S.C. Alternatives to animal testing: A review. Saudi Pharm. J. 2015, 23, $223-229$. [CrossRef] [PubMed]

102. Novohradská, S.; Ferling, I.; Hillmann, F. Exploring virulence determinants of filamentous fungal pathogens through interactions with soil amoebae. Front. Cell. Infect. Microbiol. 2017, 7, 497. [CrossRef] [PubMed]

103. Johnson, C.H.; Ayyadevara, S.; McEwen, J.E.; Shmookler Reis, R.J. Histoplasma capsulatum and Caenorhabditis elegans: A simple nematode model for an innate immune response to fungal infection. Med. Mycol. 2009, 47, 808-813. [CrossRef] [PubMed]

104. Mylonakis, E.; Ausubel, F.M.; Perfect, J.R.; Heitman, J.; Calderwood, S.B. Killing of Caenorhabditis elegans by Cryptococcus neoformans as a model of yeast pathogenesis. Proc. Natl. Acad. Sci. USA 2002, 99, 15675-15680. [CrossRef]

105. Scorzoni, L.; de Lucas, M.P.; de Lacorte Singulani, J.; de Oliveira, H.C.; Assato, P.A.; Fusco-Almeida, A.M.; Mendes-Giannini, M.J.S. Evaluation of Caenorhabditis elegans as a host model for Paracoccidioides brasiliensis and Paracoccidioides lutzii. Pathog. Dis. 2018, 76, fty004. [CrossRef]

106. Alarco, A.-M.; Marcil, A.; Chen, J.; Suter, B.; Thomas, D.; Whiteway, M. Immune-Deficient Drosophila melanogaster: A Model for the Innate Immune Response to Human Fungal Pathogens. J. Immunol. 2004, 172, 5622-5628. [CrossRef]

107. Glittenberg, M.T.; Silas, S.; MacCallum, D.M.; Gow, N.A.R.; Ligoxygakis, P. Wild-type Drosophila melanogaster as an alternative model system for investigating the pathogenicity of Candida albicans. DMM Dis. Model. Mech. 2011, 4, 504-514. [CrossRef]

108. De Souza, P.C.; Caloni, C.C.; Wilson, D.; Almeida, R.S. An invertebrate host to study fungal infections, mycotoxins and antifungal drugs: Tenebrio molitor. J. Fungi 2018, 4, 125. [CrossRef]

109. Singkum, P.; Suwanmanee, S.; Pumeesat, P.; Luplertlop, N. A powerful in vivo alternative model in scientific research: Galleria mellonella. Acta Microbiol. Immunol. Hung. 2019, 66, 31-55. [CrossRef]

110. Jemel, S.; Guillot, J.; Kallel, K.; Botterel, F.; Dannaoui, E. Galleria mellonella for the evaluation of antifungal efficacy against medically important fungi, a narrative review. Microorganisms 2020, 8, 390. [CrossRef]

111. Amorim-Vaz, S.; Delarze, E.; Ischer, F.; Sanglard, D.; Coste, A.T. Examining the virulence of Candida albicans transcription factor mutants using Galleria mellonella and mouse infection models. Front. Microbiol. 2015, 6, 367. [CrossRef] [PubMed]

112. Cotter, G.; Doyle, S.; Kavanagh, K. Development of an insect model for the in vivo pathogenicity testing of yeasts. FEMS Immunol. Med. Microbiol. 2000, 27, 163-169. [CrossRef] [PubMed]

113. Sheehan, G.; Tully, L.; Kavanagh, K.A. Candida albicans increases the pathogenicity of Staphylococcus aureus during polymicrobial infection of Galleria mellonella larvae. Microbiology 2020, 166, 375-385. [CrossRef]

114. Sheehan, G.; Kavanagh, K. Analysis of the early cellular and humoral responses of Galleria mellonella larvae to infection by Candida albicans. Virulence 2018, 9, 163-172. [CrossRef] [PubMed]

115. Brennan, M.; Thomas, D.Y.; Whiteway, M.; Kavanagh, K. Correlation between virulence of Candida albicans mutants in mice and Galleria mellonella larvae. FEMS Immunol. Med. Microbiol. 2002, 34, 153-157. [CrossRef] [PubMed] 
116. Slater, J.L.; Gregson, L.; Denning, D.W.; Warn, P.A. Pathogenicity of Aspergillus fumigatus mutants assessed in Galleria mellonella matches that in mice. Med. Mycol. 2011, 49, S107-S113. [CrossRef]

117. Hohl, T.M. Overview of vertebrate animal models of fungal infection. J. Immunol. Methods 2014, 410, $100-112$. [CrossRef]

118. Malavia, D.; Gow, N.A.R.; Usher, J. Advances in molecular tools and in vivo models for the study of human fungal pathogenesis. Microorganisms 2020, 8, 803. [CrossRef]

119. Singulani, J.L.; Scorzoni, L.; de Oliveira, H.C.; Marcos, C.M.; Assato, P.A.; Fusco-Almeida, A.M.; Mendes-Giannini, M.J.S. Applications of invertebrate animal models to dimorphic fungal infections. J. Fungi 2018, 4, 118. [CrossRef]

120. Guimaraes, A.J.; Gomes, K.X.; Cortines, J.R.; Peralta, J.M.; Peralta, R.H.S. Acanthamoeba spp. as a universal host for pathogenic microorganisms: One bridge from environment to host virulence. Microbiol. Res. 2016, 193, 30-38. [CrossRef]

121. Rakus, K.; Adamek, M.; Mojżesz, M.; Podlasz, P.; Chmielewska-Krzesińska, M.; Naumowicz, K.; Kasica-Jarosz, N.; Kłak, K.; Rakers, S.; Way, K.; et al. Evaluation of zebrafish (Danio rerio) as an animal model for the viral infections of fish. J. Fish Dis. 2019, 42, 923-934. [CrossRef] [PubMed]

122. Avendaño-Herrera, R.; Benavides, I.; Espina, J.A.; Soto-Comte, D.; Poblete-Morales, M.; Valdés, J.A.; Feijóo, C.G.; Reyes, A.E. Zebrafish (Danio rerio) as an animal model for bath infection by Flavobacterium psychrophilum. J. Fish Dis. 2020, 43, 561-570. [CrossRef] [PubMed]

123. Saraceni, P.R.; Romero, A.; Figueras, A.; Novoa, B. Establishment of infection models in zebrafish larvae (Danio rerio) to study the pathogenesis of Aeromonas hydrophila. Front. Microbiol. 2016, 7, 1219. [CrossRef] [PubMed]

124. Chao, C.C.; Hsu, P.C.; Jen, C.F.; Chen, I.H.; Wang, C.H.; Chan, H.C.; Tsai, P.W.; Tung, K.C.; Wang, C.H.; Lan, C.Y.; et al. Zebrafish as a model host for Candida albicans infection. Infect. Immun. 2010, 78, 2512-2521. [CrossRef]

125. Davis, J.M.; Huang, M.; Botts, M.R.; Hull, C.M.; Huttenlocher, A. A zebrafish model of cryptococcal infection reveals roles for macrophages, endothelial cells, and neutrophils in the establishment and control of sustained fungemia. Infect. Immun. 2016, 84, 3047-3062. [CrossRef]

126. Sabiiti, W.; May, R.C.; Pursall, E.R. Experimental models of cryptococcosis. Int. J. Microbiol. 2012, 2012, 626745. [CrossRef]

127. Powell, J.R.; Ausubel, F.M. Models of Caenorhabditis elegans Infection by Bacterial and Fungal Pathogens. In Innate Immunity. Methods in Molecular Biology ${ }^{T M}$; Ewbank, J., Vivier, E., Eds.; Humana Press: Totowa, NJ, USA, 2008; pp. 403-427. [CrossRef]

128. Matsumoto, Y.; Sumiya, E.; Sugita, T.; Sekimizu, K. An invertebrate hyperglycemic model for the identification of anti-diabetic drugs. PLOS ONE 2011, 6, e18292. [CrossRef]

129. Brunke, S.; Quintin, J.; Kasper, L.; Jacobsen, I.D.; Richter, M.E.; Hiller, E.; Schwarzmüller, T.; D’Enfert, C.; Kuchler, K.; Rupp, S.; et al. Of mice, flies-And men? Comparing fungal infection models for large-scale screening efforts. DMM Dis. Model. Mech. 2015, 8, 473-486. [CrossRef]

130. Fallon, J.; Kelly, J.; Kavanagh, K. Galleria mellonella as a model for fungal pathogenicity testing. In Host-Fungus Interactions: Methods and Protocols; Brand, A., MacCallum, D., Eds.; Humana Press: Totowa, NJ, USA, 2012; Volume 845, pp. 469-485. ISBN 9781617795381. [CrossRef]

131. Fuchs, B.B.; O’Brien, E.; El Khoury, J.B.; Mylonakis, E. Methods for using Galleria mellonella as a model host to study fungal pathogenesis. Virulence 2010, 1, 475-482. [CrossRef]

132. Scorzoni, L.; De Paula E Silva, A.C.A.; De Oliveira, H.C.; Marcos, C.M.; De Lacorte Singulani, J.; Fusco-Almeida, A.M.; Mendes-Giannini, M.J.S. Can passage in Galleria mellonella activate virulence factors of Paracoccidioides brasiliensis as in the murine model? Med. Mycol. 2018, 56, 374-377. [CrossRef]

133. Benaducci, T.; Sardi, J.d.C.O.; Lourencetti, N.M.S.; Scorzoni, L.; Gullo, F.P.; Rossi, S.A.; Derissi, J.B.; de Azevedo Prata, M.C.; Fusco-Almeida, A.M.; Mendes-Giannini, M.J.S. Virulence of Cryptococcus sp. biofilms in vitro and in vivo using Galleria mellonella as an alternative model. Front. Microbiol. 2016, 7, 290. [CrossRef] [PubMed]

134. Brilhante, R.S.N.; da Rocha, M.G.; de Melo Guedes, G.M.; de Oliveira, J.S.; dos Santos Araújo, G.; España, J.D.A.; Sales, J.A.; de Aguiar, L.; de Araújo Neto Paiva, M.; de Aguiar Cordeiro, R.; et al. Malassezia pachydermatis from animals: Planktonic and biofilm antifungal susceptibility and its virulence arsenal. Vet. Microbiol. 2018, 220, 47-52. [CrossRef] [PubMed] 
135. Silva Rabelo, A.P.; Valério, A.; Viana, R.O.; Ricoy, A.C.D.S.; Johann, S.; Alves, V.D.S. Caenorhabditis Elegans and Tenebrio Molitor-New Tools to Investigate Malassezia Species. Preprints 2018, 2018100001. [CrossRef]

136. Thomaz, L.; García-Rodas, R.; Guimarães, A.J.; Taborda, C.P.; Zaragoza, O.; Nosanchuk, J.D. Galleria mellonella as a model host to study Paracoccidioides Lutzii and Histoplasma Capsulatum. Virulence 2013, 4, 139-146. [CrossRef] [PubMed]

137. Coleman, J.J.; Muhammed, M.; Kasperkovitz, P.V.; Vyas, J.M.; Mylonakis, E. Fusarium pathogenesis investigated using Galleria mellonella as a heterologous host. Fungal Biol. 2011, 115, 1279-1289. [CrossRef] [PubMed]

138. Kloezen, W.; van Helvert-van Poppel, M.; Fahal, A.H.; van de Sande, W.W.J. A Madurella mycetomatis grain model in Galleria mellonella larvae. PLoS Negl. Trop. Dis. 2015, 9, e0003926. [CrossRef]

139. Scorzoni, L.; de Lucas, M.P.; Mesa-Arango, A.C.; Fusco-Almeida, A.M.; Lozano, E.; Cuenca-Estrella, M.; Mendes-Giannini, M.J.; Zaragoza, O. Antifungal Efficacy during Candida krusei Infection in Non-Conventional Models Correlates with the Yeast In Vitro Susceptibility Profile. PLoS ONE 2013, 8, e60047. [CrossRef]

140. Sheehan, G.; Kavanagh, K. Proteomic analysis of the responses of Candida albicans during infection of Galleria mellonella larvae. J. Fungi 2019, 5, 7. [CrossRef]

141. Mowlds, P.; Coates, C.; Renwick, J.; Kavanagh, K. Dose-dependent cellular and humoral responses in Galleria mellonella larvae following $\beta$-glucan inoculation. Microbes Infect. 2010, 12, 146-153. [CrossRef]

142. Fallon, J.P.; Troy, N.; Kavanagh, K. Pre-exposure of Galleria mellonella larvae to different doses of Aspergillus fumigatus conidia causes differential activation of cellular and humoral immune responses. Virulence 2011, 2, 413-421. [CrossRef]

143. Bergin, D.; Murphy, L.; Keenan, J.; Clynes, M.; Kavanagh, K. Pre-exposure to yeast protects larvae of Galleria mellonella from a subsequent lethal infection by Candida albicans and is mediated by the increased expression of antimicrobial peptides. Microbes Infect. 2006, 8, 2105-2112. [CrossRef] [PubMed]

144. Mesa-Arango, A.C.; Forastiero, A.; Bernal-Martínez, L.; Cuenca-Estrella, M.; Mellado, E.; Zaragoza, O. The non-mammalian host Galleria mellonella can be used to study the virulence of the fungal pathogen Candida tropicalis and the efficacy of antifungal drugs during infection by this pathogenic yeast. Med. Mycol. 2013, 51, 461-472. [CrossRef] [PubMed]

145. De Lacorte Singulani, J.; Scorzoni, L.; de Paula e Silva, A.C.A.; Fusco-Almeida, A.M.; Mendes-Giannini, M.J.S. Evaluation of the efficacy of antifungal drugs against Paracoccidioides brasiliensis and Paracoccidioides lutzii in a Galleria mellonella model. Int. J. Antimicrob. Agents 2016, 48, 292-297. [CrossRef] [PubMed]

146. Astvad, K.M.T.; Meletiadis, J.; Whalley, S.; Arendrup, M.C. Fluconazole pharmacokinetics in Galleria mellonella larvae and performance evaluation of a bioassay compared to liquid chromatography-tandem mass spectrometry for hemolymph specimens. Antimicrob. Agents Chemother. 2017, 61, 1-8. [CrossRef]

147. Vogel, H.; Altincicek, B.; Glöckner, G.; Vilcinskas, A. A comprehensive transcriptome and immune-gene repertoire of the lepidopteran model host Galleria mellonella. BMC Genom. 2011, 12, 308. [CrossRef]

148. Mukherjee, K.; Vilcinskas, A. Development and immunity-related microRNAs of the lepidopteran model host Galleria mellonella. BMC Genom. 2014, 15, 1-12. [CrossRef]

149. Torres, M.; Pinzón, E.N.; Rey, F.M.; Martinez, H.; Parra Giraldo, C.M.; Celis Ramírez, A.M. Galleria mellonella as a Novelty in vivo Model of Host-Pathogen Interaction for Malassezia furfur CBS 1878 and Malassezia pachydermatis CBS 1879. Front. Cell. Infect. Microbiol. 2020, 10, 199. [CrossRef]

(C) 2020 by the authors. Licensee MDPI, Basel, Switzerland. This article is an open access article distributed under the terms and conditions of the Creative Commons Attribution (CC BY) license (http://creativecommons.org/licenses/by/4.0/). 